\title{
Education in emergencies: Lessons from COVID-19 in South Africa
}

\author{
Nhlanhla Landa ${ }^{1}$ (D) Sindiso Zhou ${ }^{1}$ (D) Newlin Marongwe $^{2}$ (D)
}

Published online: 28 May 2021

(c) UNESCO Institute for Lifelong Learning and Springer Nature B.V. 2021

\begin{abstract}
On 11 March 2020, the World Health Organization upgraded the outbreak of COVID-19 to pandemic status. On 15 March 2020, the South African president declared a national state of disaster under the Disaster Management Act of 2002. On 26 March 2020, national lockdown, which included measures stipulated in guidelines for education in emergencies, was implemented in South Africa. The presidential declaration and subsequent lockdown came at a time when some of the universities in South Africa were already struggling either to commence the academic year, or to make up for time lost due to persistent student protests relating to several student demands. However, disaster management now entailed that all schools and institutions of higher education were forced to close immediately for extended periods, necessitating alternative ways of ensuring access to education. The qualitative case study presented in this article sought to document the intervention strategies developed by two universities located in remote parts of Eastern Cape Province to deliver education during the COVID-19 restrictions. A second aim was an examination of the challenges experienced by the two institutions' largely rural student population. The authors collected data using a questionnaire completed by 15 educators and 30 students from the two universities. They also analysed official communications documents from the universities addressed to lecturers and students. The results indicate that access to online teaching and learning platforms and resources for students from poor rural communities in South Africa is challenging, and that there are gross inequalities in educational outcomes for learners from different socioeconomic backgrounds. This affects the future plans of higher education institutions to provide teaching and learning through online-based platforms. The authors conclude their article by providing recommendations to support online learning in rural areas, which has the potential to expand higher education access post-COVID-19.
\end{abstract}

Keywords education in emergencies · COVID-19 lockdown · online learning · higher education $\cdot$ rurality

Nhlanhla Landa

nlanda@ufh.ac.za

Extended author information available on the last page of the article 


\section{Résumé}

L'éducation dans les situations d'urgence : les leçons de la COVID-19 en Afrique du Sud - Le 11 mars 2020, l'Organisation mondiale de la santé a fait passer la COVID-19 du statut d'épidémie à celui de pandémie. Le 15 mars 2020, le président sud-africain a déclaré l'état de catastrophe nationale conformément à la Loi de gestion des catastrophes de 2002. Le 26 mars 2020, un confinement national est entré en vigueur en Afrique du Sud. Il comportait des mesures conformes aux directives concernant l'éducation dans les situations d'urgence. La déclaration du président et le confinement qui a suivi sont arrivés à un moment où un certain nombre d'universités sudafricaines se battaient déjà soit pour entamer l'année universitaire, soit pour rattraper le temps perdu en raison des manifestations estudiantines persistantes liées à différentes revendications. Toutefois, la gestion de catastrophe a obligé toutes les écoles et tous les établissements d'enseignement supérieur à fermer immédiatement pour des périodes prolongées, une situation qui nécessitait de proposer d'autres solutions pour garantir l'accès à l'éducation. L'étude de cas qualitative présentée dans cet article avait pour vocation de documenter les stratégies d'intervention mises en œuvre par deux universités situées dans des régions reculées de la province d'Eastern Cape pour poursuivre leur mission d'enseignement pendant la période de restrictions imposées par la COVID-19. Elle se proposait également d'examiner les défis qui s'étaient posés aux étudiants de ces deux établissements, essentiellement issus de zones rurales. Les auteurs ont recueilli des données grâce à un questionnaire auquel ont répondu 15 enseignants et 30 étudiants de deux universités. Ils ont aussi analysé les documents de communication officiels des universités adressés aux maîtres de conférences et aux étudiants. Les résultats indiquent que l'accès à l'enseignement en ligne et aux plateformes et ressources d'apprentissage pour les étudiants de communes rurales pauvres d'Afrique du Sud est difficile, et que les résultats des apprenants sont très inégaux en fonction de leur milieu socio-économique. Ceci influera sur les plans à venir que les établissements d'enseignement supérieur développeront en matière d'enseignement et d'apprentissage pour les plateformes en ligne. Les auteurs concluent leur article en recommandant de soutenir un apprentissage en ligne susceptible d'élargir l'accès à l'enseignement supérieur après la crise de la COVID-19 dans les zones rurales.

\section{Introduction}

While research into education in emergencies generally refers to war-torn countries, regions hit by natural disasters, and political and war refugees living in refugee camps, teaching and learning during events of the magnitude of the global COVID19 pandemic is a new phenomenon in South Africa. Starting with the national state of disaster declared by the South African president on 15 March 2020 (RSA 2020a), the pandemic has resulted in several life-changing developments in the country, as has been the case around the world. In particular, the field of higher education has experienced a considerable impact. What makes the South African context interesting is that several of the nation's 26 public universities were already struggling before the outbreak of the pandemic due to ongoing student protests over a number of issues, including dissatisfaction with accommodation (Mokhoali 2020), 
university management (Magubane 2020) and student registration exclusion tuition debts (Meyer 2020). In early 2020, some of the protests had become violent, leading to the temporary closure of some universities (Grobler 2020; Kajee 2020) and the arrest of several students (Bhengu 2020). Therefore, learning in some South African universities had not yet started for the year when COVID-19 necessitated the closure of all campuses.

The study we describe in this article sought to document the interventions that higher education institutions in South Africa developed to deliver education during both the national state of disaster and the national lockdown (initially implemented on 26 March 2020 for 21 days, but eventually lasting for several months). ${ }^{1}$ The national state of disaster restricted travel and banned gatherings of more than 100 people (later reduced to 50). The national lockdown further tightened these restrictions, including country-wide social (physical) distancing and stricter travel rules, such as closing all of the nation's borders. These measures made face-to-face teaching and learning impossible.

Implemented in late March, the national lockdown occurred when universities were already pursuing several online options to save the academic calendar. In our study, we were particularly interested in universities serving a rural student population. This bias was influenced by our assumption that any innovations developed would involve online platforms. In South Africa, online learning is ordinarily less accessible to rural compared to urban populations. However, several other challenges also stood in the way of delivering education to South African students, especially those in rural areas. These challenges are further explored in the following sections of this article.

\section{Education in emergencies}

Education in emergencies, as in the case of the COVID-19 pandemic, generally relies on basic technological access. However, in such emergencies, poor communities are vulnerable and access to technology for reasons other than basic survival and obtaining essential information is a luxury. Indeed, the number of South Africans newly unemployed (Manyane 2020) due to COVID-19 has forced many to survive on food parcels from the government and other agencies (BBC News 2020), and has reduced access to education for learners from poor families.

A significant proportion of the South African student population lives in a rural area. H. Plecher (2020) indicates that in 2019, the urban population of South Africa was around $66 \%$ of the country's total population. This reflects the distribution of the student population, specifically in provinces like Eastern Cape, Mpumalanga and Limpopo, which are generally described as rural. Pierre Du Plessis and Raj Mestry (2019) conclude that, independent of COVID-19, the government of South Africa has been struggling to deliver quality teaching and learning to the country's rural

\footnotetext{
1 Schools and universities did not begin to reopen until 8 June 2020, forcing some universities to carry the 2020 academic year over into 2021 .
} 
areas. According to Michael Gardiner (2008), the legacy of poverty and neglect in former "homelands", ${ }^{2}$ which are mostly located in the Eastern Cape, KwaZulu Natal and Limpopo provinces, is far from eradicated. The state of rural education in South Africa has its roots in apartheid and its policies of dispossession (DoE 2005). Besides poor road networks, lack of electricity and low economic status, rural communities have limited access to information and communications technology (ICT) (Hlalele 2012). During the COVID-19 pandemic, "not enough attention has been given to rural education", and "COVID-19 and the implementation of online learning has magnified the challenges faced by rural learners and teachers" (Dube 2020, p. 138), consequently marginalising them.

Research indicates that higher education institutions are often required by circumstances to modify curriculum to suit learner contexts; however, we maintain that this generally favours urban students. This is because curricular "improvements" are mainly influenced by technological advancements, which are available in urban areas long before they reach rural settings. For decades, the changing learner context has required a move from traditional classrooms to a combination of physical and virtual spaces (Suorsa and Eskilsson 2014). This has resulted in the emergence of learning management systems (LMS), course management systems (CMS) and virtual learning environments, which include Moodle, Blackboard Learn, Sakai and other web-based systems. However, to realise their full potential for all students, these new tools must be selected and adapted to suit the context of learners (Ssekakubo et al. 2012), otherwise they will fail (Ssekakubo et al. 2014). For example, while the benefits of digital learning are immense for developing countries, adopting learning systems from developed countries without adapting them to local contexts will not work (Khan et al. 2010; Khan 2004); to be successful, they must match the contexts of local learners.

Literature on the impact of COVID-19 on education is still building. ${ }^{3}$ However, as early as March 2020, governments and higher education institutions all over the world were already in panic mode. In Africa in general, and South Africa in particular, this inspired a leap into remote and online learning necessitated by a desire to save the academic year. As a result, the government of South Africa collaborated with several non-governmental entities to devise ways of continuing delivery of education. Several initiatives emerged based on online, mobile and social media platforms, including the Science, Technology, Engineering and Mathematics (STEM) Lockdown Digital School, Microsoft Teams, Zoom and WhatsApp groups. The government also collaborated with various mobile network providers to offer "zero-rated"4 educational applications (apps). However, despite these efforts, South Africa's education system was ill-prepared (Dube 2020). Since the country has not

\footnotetext{
${ }^{2}$ In South Africa, homelands refer to areas created by the apartheid government under the 1959 Promotion of Bantu Self-Government Act. Their purpose was to facilitate settling Black people and granting them independence and self-government rights, which had the effect of denying Black South Africans political rights in South Africa.

3 This article was first drafted in May 2020.

4 The term zero-rated refers to free data offered to higher education institutions by service providers during the COVID-19 crisis.
} 
experienced any major epidemics in the past few years, there was little in place to deal with an emergency of this nature, and different learner contexts remained a major factor in South Africa's efforts to deliver education during the COVID-19 pandemic.

With the exception of the Angolan Civil War which ended in 2002, and internal conflict in Mozambique between 2013 and 2014, Southern Africa has not had any educational emergencies related to armed war since South Africa gained freedom in 1994. The same may not be said of West Africa, North Africa, the Horn of Africa, Central Africa or the African Great Lakes, where there are currently several armed conflicts. These conflicts have been a major cause of emergencies in sub-Saharan Africa, with both boys and girls often finding themselves involved in war either as child soldiers or as providers of services to the militia (UNICEF 2015). However, the motivation for the Dakar Framework for Action (UNESCO 2000), adopted at the Dakar World Education Forum in 2000, was that while educational losses were greatest in war-torn countries, "built often on a weak physical and institutional base, education systems in many African countries are vulnerable to natural and humanmade disasters that have hindered progress ..." (ibid., p. 25).

Therefore, COVID-19 found the education systems of many countries in Southern Africa in the process of implementing recommendations from the Dakar Framework for Action, as well as from the United Nations Educational, Scientific and Cultural Organization (UNESCO), the United Nations' Sustainable Development Goals (SDGs), and several other educational organisations and treaties. UNESCO (2016) asserts that there is a lot that still needs to be done in Southern Africa to achieve quality education by 2030 . South Africa has also been facing challenges in ensuring education for all, specifically in terms of inclusive education (Donohue and Bornman 2014; Ladbrook 2009) and digital learning (Pholotho and Mtsweni 2016).

\section{The current study}

The study we present in this article aimed to document the intervention strategies developed by two universities located in a rural province in South Africa to deliver education during the COVID-19 restrictions. Our research also sought to examine the challenges associated with the new ways of learning for a largely rural student population. To address these areas, we conducted a qualitative case study that utilised a questionnaire and document analysis to obtain data. In the following sections, we present our research methodology, discuss our findings, and provide our conclusion and recommendations.

\section{Research methodology}

Our research team comprised the three authors of this article. We conducted our study between March and June 2020. Several follow-ups were made afterwards. As already mentioned in the introduction, we were particularly interested in universities serving a rural student population. Based on our assumption that all universities' 
strategies to maintain delivery of education would involve online platforms, we expected university lecturers and students forced to operate from their underserved village homes to be subjected to a particularly challenging experience of trying to teach and learn. Our particular interest led us to choose our two sample universities, referred to as University $\mathrm{X}$ and University $\mathrm{Y}$ in this article. ${ }^{5}$

Our qualitative case study employed purposive sampling to identify and seek responses from educators (lecturers) and students from the Faculty of Education at University $\mathrm{X}$ and from the Faculty of Social Sciences and Humanities at University Y. Both universities are located in remote parts of the province of Eastern Cape in South Africa. The majority of students in this province live in rural villages, on farms and in informal settlements, ${ }^{6}$ where there are difficulties in establishing and maintaining network connectivity. South Africa is known for its high levels of inequality (World Bank 2018), and glaring inequalities can be found in rural areas of provinces such as Eastern Cape, where the majority of the population rely on monthly government grants. A month before the COVID-19 lockdown, increases to government grants (equating to an overall $4.5 \%$ increase) resulted in grants ranging from the lowest ( 445 or about USD 29.62) for child support to the highest ( 1880 or USD 125.14) for persons over the age of 75 and war veterans.

Our two sample universities are situated in remote parts of Eastern Cape province, surrounded by villages that depend mostly on government grants. Both institutions are located in socially and historically disadvantaged communities because of the policies of the apartheid government prior to 1994. Owing to their rural location, it was particularly difficult for these universities to suddenly transition from face-toface to online teaching and learning (Mbodila et al. 2016). For instance, neither of the communities has an adequate ICT infrastructure able to abruptly support online teaching and learning activities. Eastern Cape has electricity and network connectivity problems, a state of affairs which affects education programmes that need both (Steyn and Van Greunen 2014). In the discussion section, we report that some of the students in our study needed to walk long distances to access mobile phone connectivity, which would allow them to access the internet, depending on whether or not they had "data bundles" (service provider packages for internet access). These conditions made the students "digital strangers" (Prensky 2001).

Our sample was made up of 45 participants drawn from the two universities. Of these, 30 were students (17 female, 13 male) and 15 were lecturers ( 6 female, 9 male). Including lecturers and students from one faculty per university was practical and viable since the students were accessible via group e-mails and WhatsApp groups, while the lecturers were contactable through faculty group e-mails. Ethics approval was sought from both institutions, and several ethical considerations were made.

\footnotetext{
5 The purpose is to protect the privacy of our participants. We also refer to their communities as Community A, B, etc.; and to participants as Student 01, 02, etc. and Lecturer A, B, etc.

${ }^{6}$ Informal settlements in South Africa are housing areas on municipal land that are often illegally erected by the poor at the margins of big cities. Because they are illegal, these informal settlements are often characterised by absence of social amenities such as running water, clinics, electricity etc.
} 
To collect data from our respondents, we designed a qualitative questionnaire, entitled Learning possibilities and opportunities of education in emergencies: Lessons from the COVID-19 era in South Africa. Information about the study was e-mailed to the study participants alongside the questionnaire and included a consent form, which was signed and returned with the completed questionnaire. Participants were assured of confidentiality and anonymity of their participation. We distributed our survey to 15 lecturers and 30 students in the two university faculties by email, and received 30 filled-in questionnaires from students and 15 from lecturers. The qualitative questionnaire was designed to solicit responses to open-ended questions. The questions were divided into four sections (A-D):

- Section A focused on questions about the online teaching and learning tools that were deployed during the COVID-19 lockdown;

- Section $B$ included questions on the online teaching and learning experiences of both lecturers and students;

- Section $C$ concentrated on challenges associated with online-based teaching and learning processes in the specific context of the students and lecturers; and

- Section $D$ focused on lessons learnt from the COVID-19 pandemic in relation to online teaching and learning.

The open-ended questions focused on challenges associated with the new ways of teaching and learning under COVID-19 restrictions from student and lecturer perspectives. After completion of the survey, we categorised responses into specific themes for analysis. These themes are summarised in Table 1. We drew conclusions by reflecting on the emerging and frequent thematic patterns. In addition, third-year student participants shared some WhatsApp communications with us, which complemented our analysis of the questionnaire responses.

A second strand of our data collection involved an analysis of official communications from the two universities addressed to their lecturers and students. We performed a document analysis of circulars (letters), memoranda and emergency policies related to the pandemic and the resultant shifts to teaching and learning that university management had circulated to lecturers and students via websites, daily online bulletins and e-mail. From these, we sought to understand the context of what was taking place in the education programming of the two institutions. These documents also provided insights into the different innovations the universities were experimenting with.

\section{Discussion of findings}

We found that the two rural-located universities in our study adopted similar strategies in response to COVID-19 and the unanticipated closure of campuses. In the early stages of lockdown, these institutions deployed three categories of e-mail communications to students and staff, which we categorised as "COVID-19 Knowledge Awareness", "Institutional Response to COVID-19 Pandemic" and "Online 


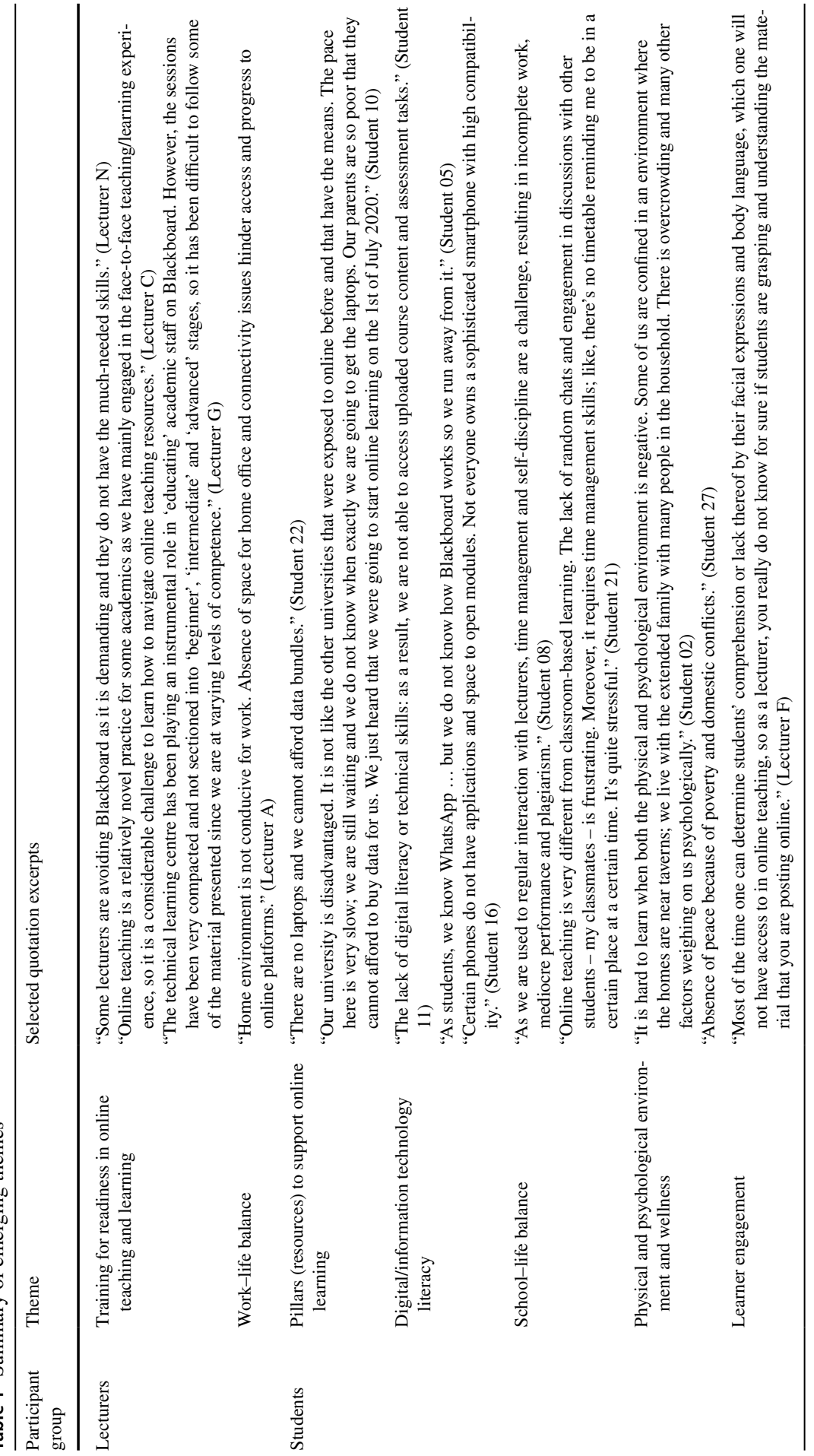


Teaching Strategy". As the pandemic progressed, the universities continued to roll out regular communications to inform and alert their stakeholders about current events and the unprecedented changes to the status quo. This section presents and discusses our findings from these institutional communications (including circulars, memoranda and emergency policies), and from lecturer and student responses to our questionnaire.

\section{COVID-19 knowledge awareness and institutional response to the pandemic}

Higher education institutions across South Africa shared information about COVID19 on websites and via e-mails from the moment the South African president declared a national state of disaster, and consequently when the Minister of Higher Education, Science and Innovation issued a statement of action (RSA 2020b). Social distancing, hand washing and mask wearing were advocated, alongside isolation and quarantine in confirmed cases of COVID-19 infection.

The respective administration departments of the two universities in our study took responsibility for informing their stakeholders about the measures being put in place in response to the COVID-19 protocols approved by the World Health Organization (WHO). In that regard, memoranda and circulars were posted on university websites and often e-mailed directly to the university communities to keep them informed. According to these communications, management responsibilities included sending students who were living on campus away, which required hiring buses and providing funding for local and international students who were not financially prepared to take unplanned trips. University X provided off-campus accommodation for international students who had not managed to travel home by the time the national lockdown took effect. This was because the usual on-campus student support in the form of cleaning, security and canteen services was cancelled as soon as the university had shut down.

\section{Online teaching strategy}

Both universities already had an online presence, with online learning platforms being used to share learning materials alongside face-to-face instruction. Both institutions were also attempting to use the internet to foster collaborative knowledge acquisition. Post-lockdown, the universities shared communications on the modalities of harnessing this existing online space for all teaching and learning while physical contact was prohibited. Directions were given on the shift to remote and online teaching through harnessing learning technology, as posited by Tony Bates (2015). This resulted in teaching using online platforms such as WhatsApp, Blackboard, YouTube and many other online-based teaching innovations. Specifically, University $\mathrm{Y}$ adopted an online teaching and learning intervention supported by an emergency policy which involved the physical delivery of study materials to under-digitalised 
students and the provision of compressed face-to-face teaching and learning whenever students were able to return to campus.

\section{Complexity of technical communications}

Both lecturers and students in our study sample indicated their struggle with the challenge of understanding technical communications from the respective university information and communications departments and teaching and learning centres. The institutional e-mails sent often outlined technical instructions for lecturers and students to follow to access particular benefits, such as zero-rated data and websites for teaching and learning. However, no prior instruction on terminology had been offered. The assumption seems to have been that the student and staff population should already be aware of the discourses of their community. Our participants indicated that most communications left them more confused than informed. Our analysis of the participant responses, as well as of the communications themselves, indicates that the responsibility for introducing new ways of learning and accessing learning materials was often left to non-teaching personnel who, despite being knowledgeable on the subject, were not trained to communicate with students.

\section{Limitations of network connectivity and access}

The economic and institutional shutdowns prompted by the outbreak of the COVID19 pandemic completely changed the teaching and learning trajectory in South African higher education, and affected the possibility and progress of students' learning. In our study, participant responses reflected that while national lockdown was not solely responsible for the downturn of events, in effect it made an already bad situation worse. Essentially, it exposed national inequalities, inefficiency of government processes and institutional weaknesses already extant before the onset of the pandemic. One of the main concerns raised by both students and lecturers was the lack of digital literacy (technical skills), which is critical in higher education globally in the 21 st century.

The majority of students in our sample stated that they had experienced issues with data accessibility, and thus were struggling or failing to access learning resources remotely. One student indicated that she had to leave her home in Community $\mathrm{B}$ to seek accommodation with a maternal aunt working and residing in Town CB so she could access e-mails on her relative's smartphone. Several other students indicated that they had to walk long distances to find mobile network connectivity strong enough to allow connection to the internet. One student's response said:

The inability to access the internet due to lack of network signal and data has been a struggle for me. On the other hand, I find it difficult to study at home; there are many distractions. This has left me demotivated. (Student 03)

Overall, resource constraints - such as access to computers and data for students from poor communities - were a key challenge in the lockdown. The two universities 
in our study pledged to support students by providing laptops and zero-rated data. However, as expected, these noble pronouncements also involved bureaucratic and administrative processes that did not necessarily proceed in a timely fashion. Further, despite the Department of Higher Education and Training (DHET) pledging to support students and promising to ensure that "no student is left behind", the challenges of self-study and self-supervision on the internet remained a struggle for the majority of students who had no alternative but to return to their villages upon institutional closures. Due to data costs and the fixed amount of data provided by their institutions, students in our study indicated that they encountered challenges in downloading certain types of course material, such as lectures posted in PowerPoint format with voice-overs and embedded videos. In particular, the third-year students, whose WhatsApp group comments were included in this study, frequently asked their lecturers to post on WhatsApp whatever would have been uploaded on Blackboard, since they were failing to access course materials on this LMS.

\section{Information technology literacy, training and readiness for online learning}

The responses from both lecturers and students indicated a general lack of readiness and preparedness for utilising online resources, including the anticipated challenges that would be faced by students with disabilities (in particular, adaptability and transition). Although students were already using some online resources in their studies, the sudden crossover to solely online learning caused by the pandemic raised many questions on adaptability, focus and the pacing of academic progress. This affected students emotionally. One student commented:

What online classes are you talking about? We have not yet started; we just hear on the television and radio that university students are doing remote learning. Maybe they will be talking about other advantaged universities, not us. We have not yet received the data and laptops that the minister spoke about. (Student 22)

In our study, it became apparent that institutions, staff and students were not prepared for this kind of disaster that saw everybody locked down for an extended period.

\section{Problems in measuring learner engagement with online content}

During the lockdown, students found themselves stuck in environments that were not conducive to learning, and where survival was more important than pursuing higher education. As a result, lecturers in our study expressed their uncertainty as to whether students were engaging with content online, especially where large groups were concerned. Lecturers indicated that online learning in itself was overwhelming for students accustomed to face-to-face teaching and guidance. In addition, there was pressure on lecturers to upload large quantities of course material at the same time, without an appropriate and relevant tool to actually measure if any constructive engagement was happening on the part of the students. Students also indicated 
that lecturers were not taking them through learning content systematically, topic by topic, as they would have done in a face-to-face situation. They described their experiences as "abnormal", "difficult", "demanding" and "tricky".

It also emerged that since students were not adequately trained in the use of learning technologies - with first-year students not trained at all - they were at different levels of competence. This resulted in lecturers struggling to deliver content to students, since they often found themselves teaching students how to use the technology rather than delivering subject content. Many lecturers struggled with online teaching. One said:

I have not yet grabbed how to communicate with students beyond uploading and arranging materials on Blackboard. (Lecturer D)

After the lockdown, lecturers were receiving training on how to use several online platforms, because even though these platforms had been available before the pandemic, many had not been using them. In one of the two universities, an existing technical learning centre was playing an instrumental role in "educating" academic staff regarding the use of the Blackboard LMS. However, the sessions were described as compacted and not sectioned into beginner, intermediate and advanced stages, making it difficult for some to follow the materials presented.

Lecturers also reported that assessment was a challenge. One lecturer indicated that:

Online assessment is generally difficult; imagine marking 100 essays online and sending them back to students via e-mail. The admin is challenging and time-consuming. (Lecturer J)

Some lecturers were deeply concerned about the submission of assessments. Prior to the pandemic, students typically handed in an Academic Essay Portfolio for assessment, and lecturers were unsure how this would work in an online system. Assessment was also flagged as a challenge because some students would claim that they had experienced connectivity issues if they had missed assessment deadlines. This was potentially retrogressive for student achievement, especially with large classes characterising campuses in rural spaces.

Overall, at the beginning of the teaching interventions prompted by the outbreak of the COVID-19 pandemic, lecturers expressed their reservations about online learning - notably that it might be overwhelming for students who, without training, were presented with too much information without a "human face" to explain and provide assurance. They feared this could lead to increased dropout and high failure rates simply because learners (and their parents) were dreading the online platforms. Both lecturers and students expressed the need for personal engagement to establish a connection where they felt "safe" and comfortable to voice their opinions and problems. 


\section{School-life balance, work-life balance and psychological unwellness}

Responses from student participants indicated that they were experiencing psychological distress precipitated by an indefinite confinement in a less-than-ideal physical environment. With a large population of students locked down in informal settlements and villages - where access to the requisite infrastructure for online learning was difficult - frustration, anxiety and psychological distress were unavoidable. Given the ordinarily high emotional distress among university students in South Africa in the absence of a pandemic, a significant rise in psychological unwellness due to COVID-19 is highly likely. Similar to the dilemma faced by students, lecturers also struggled to work from home. The call to work and study remotely was a general call that did not consider those with space challenges. In the absence of a home office, desk or quiet space in which to concentrate, participants indicated that balancing home life and work/study was stressful. Confinement with limited resources, coupled with the anxiety of contracting COVID-19, resulted in participants' belief that the lockdown would leave them worse off psychologically. Notably, the uncertainty and imperceptible nature of the pandemic triggered a negative emotional response in both students and lecturers.

\section{Summary of themes}

As discussed above, several themes emerged from the data collected in our study. Two of them concern the lecturers, while the other five are especially relevant for the students. These themes are summarised in Table 1 and are illustrated by selected quotation excerpts from participants.

\section{Conclusion and recommendations}

In our study, triangulation of the data from the qualitative questionnaire to lecturers and students, along with our document analysis, indicated that the two universities were quick to harness the virtual space and to plan for practical online learning in response to the COVID-19 restrictions. In the interim, they communicated the commencement of preliminary steps to lecturers and students, including the uploading of learning materials on the Blackboard LMS. This provided reassurance that the disruption to education would be temporary. While the boost to online teaching and learning would come from providing laptops and data to students, by the 112th day of the national lockdown (in mid-July 2020), some higher education institutions (including the two universities in our study) had still not delivered these resources due to logistical delays, thus greatly disadvantaging rural learners.

By the beginning of February 2021, many universities across Africa were yet to conclude the 2020 academic year. Our findings indicate that both lecturers and students were experiencing challenges, ranging from being able to access the internet to learning how to competently navigate the online learning space. Emerging themes in our study revealed that issues included training for readiness in online teaching 
and learning, work-life balance, school-life balance, pillars (resources) to support online learning, digital/information technology literacy, physical and psychological environment and wellness, and learner engagement. Given that network connectivity - which affects access to mobile network-based data and learning applications - was a major challenge, we recommend that government collaborate with network providers to facilitate connectivity in rural areas. In addition, the provision of zerorated data currently benefits mostly urban learners, so access also needs to be given to rural learners from formerly marginalised universities.

We recommend swift intervention, not only because scientists predict that the COVID-19 pandemic and its aftermath will be around for some time, but also because there is potential for online learning to facilitate increased access to higher education for those universities that have previously been unable to accommodate student demand due to infrastructure limitations. An additional and crucial consideration in education during emergencies is that of digital literacy. A deliberate capacity-building initiative to train both educators and students would be instrumental in ensuring a smooth and successful transition from conventional to virtual classrooms. The South African government needs to act quickly to make online learning a viable reality, especially for learners in rural areas who need support to access and benefit from this relatively new learning experience. Government should also provide resources to higher education institutions so they can package support interventions that are informed by learner-specific contexts. Importantly, equipping educators and students for online learning has the potential to expand access to higher education post-COVID-19.

\section{References}

Bates, A. W. (2015). Teaching in a digital age. Vancouver, BC: Tony Bates Associates Ltd.

BBC (British Broadcasting Corporation) (2020). Coronavirus: South Africans in massive queues for food parcels. BBC News, 17 May [online news item]. Retrieved 3 June 2020 from https://www.bbc.com/ news/av/world-africa-52701571.

Bhengu, L. (2020). Four UKZN students arrested, security building petrol-bombed in fees protest Times Live, 29 January [online news item]. Retrieved 13 February 2020 from https://www.timeslive.co.za/ news/south-africa/2020-01-29-ukzn-security-building-petrol-bombed-during-student-protest/.

DoE (Department of Education). (2005). Reflections on rural education in South Africa. Pretoria: Government Printers.

Donohue, D., \& Bornman, J. (2014). The challenges of realising inclusive education in South Africa. South African Journal of Education, 34(2), Art. 806. Retrieved 12 June 2020 from https://journals. co.za/content/educat/34/2/EJC153713.

Dube, B. (2020). Rural online learning in the context of COVID-19 in South Africa: Evoking an inclusive education approach. Multidisciplinary Journal of Educational Research, 10(2), 135-157. https:// doi.org/10.4471/remie.2020.5607.

Du Plessis, P., \& Mestry, R. (2019). Teachers for rural schools - a challenge for South Africa. South African Journal of Education, 39(Suppl, 1), Art. 1774. https://doi.org/10.15700/saje.v39ns1a1774.

Gardiner, M. (2008). Education in rural areas. Issues in Education Policy, No. 4. Johannesburg: Centre for Education Policy Development (CEPD).

Grobler, R. (2020). All Fort Hare campuses to be evacuated amid "intimidation and violence" News 24 , 5 March [online news item]. Retrieved 3 June 2020 from https://www.news24.com/SouthAfrica/ News/just-in-all-fort-hare-campuses-to-be-evacuated-amid-intimidation-and-violence-20200305.

Hlalele, D. (2012). Social justice and rural education in SA. Perspectives in Education, 30(1), 111-118. 
Kajee, A. (2020). UKZN protests turn violent as students, security clash. Eye Witness News, 19 February [news video]. Retrieved 12 March 2020 from https://ewn.co.za/video/11153/ukzn-protests-turnviolent-as-students-security-clash.

Khan, B. H. (2004). The people-process-product continuum in e-learning: The e-learning P3 model. Educational Technology, 44(5), 33-40.

Khan, G. F., Moon, J., Moon, R. C., \& Rho, J. J. (2010). E-government skills identification and development: Toward a Staged-Based User-Centric Approach for developing countries. Asia Pacific Journal of Information Systems, 20(1), 1-30.

Ladbrook, M.W. (2009). Challenges experienced by educators in the implementation of inclusive education in primary schools in South Africa. Master's thesis, University of South Africa, South Africa. Retrieved 18 March 2021 from http://uir.unisa.ac.za/handle/10500/3038.

Magubane, T. (2020). UniZulu to remain closed for remainder of the week. The Mercury, 10 March [online news item]. Retrieved 3 June 2020 from https://www.iol.co.za/mercury/news/unizulu-toremain-closed-for-remainder-of-the-week-44502875.

Manyane, M. (2020). Labour unions scramble to save jobs amid the COVID-19 outbreak in SA. Sunday Independent, 3 May [online news item]. Retrieved 14 June 2020 from https://www.iol.co.za/ sundayindependent/news/labour-unions-scramble-to-save-jobs-amid-the-covid-19-outbreak-insa-47491247.

Mbodila, M., Bassey, I., \& Kikunga, M. (2016). On overcoming transitional challenges of first year students in technology-based educational settings. Modern Education and Computer Science, 11, 28-35. https://doi.org/10.5815/ijmecs.2016.11.04.

Meyer, D. (2020). UWC gets the ball rolling but UKZN remains engulfed in student protest: Usaf say that most universities across the country finally have their noses in the books, but UKZN remains volatile. The South African, 11 February [online news item]. Retrieved 13 February from https:// www.thesouthafrican.com/news/student-protests-uwc-ukzn-wits-university-february-2020/.

Mokhoali, V. (2020). Wits University students protest over lack of accommodation. Eye Witness News, 4 March [online news item]. Retrieved 3 June 2020 from https://ewn.co.za/2020/03/04/ wits-university-students-protest-over-lack-of-housing.

Pholotho, T., \& Mtsweni1, J. (2016). Barriers to electronic access and delivery of educational information in resource-constrained public schools: A case of Greater Tubatse Municipality. In P. Cunningham \& M. Cunningham (Eds), IST-Africa 2016 Conference Proceedings, 11-13 May (pp. 1-9) [online]. Durban: International Information Management Corporation (IIMC)/Innovation, Science and Technology (IST)-Africa. Retrieved 10 June 2020 from https://researchspace. csir.co.za/dspace/bitstream/handle/10204/9340/Pholotho_18155_2016.pdf?sequence=1\&isAll owed $=\mathrm{y}$.

Plecher, H. (2020). South Africa: Urbanization in South Africa from 2009 to 2019 [online database]. New York, NY: Statista Inc. Retrieved 12 January 2021 from https://www.statista.com/statistics/ 455931/urbanization-in-south-africa/.

Prensky, M. (2001). Digital natives, digital immigrants: Part 1. On the Horizon, 9(5), 1-6. https://doi. org/10.1108/10748120110424816.

RSA (Republic of South Africa) (2020a). Declaration of a national state of disaster under the Disaster Management Act of 2002. Government Gazette, 15 March. Retrieved 3 May 2021 from https:// www.gov.za/sites/default/files/gcis_document/202003/43096gon313.pdf.

RSA (2020b). Minister Blade Nzimande: Higher Education and Training updated response to Coronavirus Covid-19 [online media statement, $28 \mathrm{March}$ ]. Retrieved 12 May 2021 from https://www. gov.za/speeches/minister-blade-nzimande-higher-education-training-updated-response-coron avirus-covied-19-28.

Ssekakubo, G., Suleman, H., \& Marsden, G. (2012). Learning management systems: Understanding the expectations of learners in developing countries. In P. Kommers, P. Isaías \& N. Bessis (Eds), Proceedings of the IADIS International Conference Web Based Communities 2012, Lisbon,17-23 July, (pp. 251-260). Lisbon: International Association for Development of the Information Society (IADIS). Retrieved 18 March 2021 from https://pubs.cs.uct.ac.za/id/eprint/790/.

Ssekakubo, G. Suleman, H., \& Marsden, G. (2014). A streamlined mobile user interface for improved access to LMS services. In S. White (Ed.), Proceedings of the Sixth International Conference on Mobile, Hybrid, and On-line Learning eLmL 2014, Barcelona, 23-27 March, (pp. 92-101). Wilmington, DE: International Academy, Research, and Industry Association (IARIA). Retrieved 18 March 2021 from https://www.thinkmind.org/articles/elml_2014_4_40_50031.pdf. 
Steyn, J., \& van Greunen, D. (Eds) (2014). ICTs for inclusive communities in developing societies: Proceedings of the 8th International Development Informatics Association Conference, Port Elizabeth, 3-4 November. Newcastle upon Tyne: Cambridge Scholars Publishing. Retrieved 9 January 2021 from http://www.developmentinformatics.org/conferences/.../20-Nkula- Kirsten. pdf.

Suorsa, J., \& Eskilsson, N. (2014). Students' perceptions of learning management systems: An explorative case study of upper secondary school students (Bachelor's dissertation). Department of Applied Information Technology, University of Gothenburg, Sweden. Retrieved 10 June 2020 from https:// core.ac.uk/download/pdf/43556451.pdf.

UNESCO (United Nations Educational, Scientific and Cultural Organization) (2000). Dakar framework for action. Education for all: Meeting our collective commitments. Paris: UNESCO. Retrieved 13 April 2021 from http://unesdoc.unesco.org/images/0012/001211/121147e.pdf.

UNESCO (2016). Education in emergencies and protracted crises in sub-Saharan Africa: Developing inclusive, responsive, resilient education services for all. Education 2030 Brief, Volume 2, September. Paris: UNESCO. Retrieved 13 April 2021 from https://unesdoc.unesco.org/ark:/48223/pf000 0261658 .

UNICEF (United Nations Children's Fund) (2015). Ending the recruitment and use of children in armed conflict. London: UNICEF United Kingdom. Retrieved 18 March 2021 from https://www.unicef. org.uk/publications/child-soldiers-briefing/.

World Bank (2018). Overcoming poverty and inequality in South Africa. An Assessment of Drivers, Constraints and Opportunities. Washington, DC: International Bank for Reconstruction and Development/World Bank. Retrieved 20 June 2020 from shttp://documents.worldbank.org/curated/en/53048 1521735906534/pdf/124521-REV-OUO-South-Africa-Poverty-and-Inequality-Assessment-Report2018-FINAL-WEB.pdf.

Publisher's Note Springer Nature remains neutral with regard to jurisdictional claims in published maps and institutional affiliations.

Nhlanhla Landa, PhD, is a senior lecturer at the University of Fort Hare in South Africa. His research interests include multilingualism, language and politics, higher education reform, gender justice, as well as onomastics. He has published vastly on these and other sociolinguistic subjects in the past few years. Dr Landa teaches courses in Applied Linguistics within the Faculty of Social Sciences and Humanities.

Sindiso Zhou, $\mathrm{PhD}$, is a senior lecturer teaching Applied Linguistics in the Department of English at the University of Fort Hare in South Africa. She does research in the fields of language contact, language pedagogy, multilingualism, multilingual writing, translanguaging, higher education, onomastics, and interconnections of discourses of gender and communication in society.

Newlin Marongwe, $\mathrm{PhD}$, is a senior lecturer in the department of School Improvement Programmes at Walter Sisulu University in South Africa. Her research interests include educational psychology, higher education, education \& technology, education \& HIV/AIDS, inclusive education, decolonisation \& transformation of higher education curricula and teacher education.

\section{Authors and Affiliations}

\section{Nhlanhla Landa ${ }^{1}$ (D) Sindiso Zhou ${ }^{1}$ (D) $\cdot$ Newlin Marongwe $^{2}$ (D)}

Sindiso Zhou

szhou@ufh.ac.za

Newlin Marongwe

nmarongwe@wsu.ac.za

1 Department of English and Comparative Literature, University of Fort Hare, Alice, South Africa 
2 Department of School Improvement Programmes, Walter Sisulu University, Queenstown, South Africa 